\title{
ENTREPRENEURSHIP EDUCATION AND MANAGERIAL COMPETENCE AMONG SMES IN ANAMBRA STATE, NIGERIA.
}

\author{
Ndubuisi-Okolo Purity.U.(Ph.D) \\ Department of Business Administration, \\ Faculty of Management Sciences, \\ Nnamdi Azikiwe University, \\ Awka, Anambra, Nigeria.
}

\author{
Attah Emmanuel Yusuf(Ph.D) \\ Department of Business Administration, \\ Kogi State Polytechnic, \\ Lokoja
}

\author{
Chime .U.F. \\ Department of Business Administration, \\ Kogi State Polytechnic, \\ Lokoja
}

Article DOI: https://doi.org/10.36713/epra4421

\begin{abstract}
Business activities among traders in Anambra State seem to be changing from what it was formerly known for especially the Small Scale businesses. This is because of globalization, inadequate financial resources, poor business connections, paucity of experience, inability to cope with competition, poor sales and high stock of inventory, high operating costs as a result of poor infrastructure, inefficient management, poor business education. This study set out to ascertain the extent to which entrepreneurship education affects managerial competence among traders in Anambra State; to ascertain the effect of participating in business workshop on performance of SMES in Anambra State; and to determine the effect of acquired technical know-how on the turnover of SMES in Anambra State. Research questions and hypotheses were set in line with the objectives of the study. The study adopted a survey research design and a sample size of 196 respondents were drawn from a total population of 386 SMEs of the two selected cities in Anambra State. Although 180 copies of the questionnaire were correctly filled, returned and used for the analysis. Descriptive statistics was used for the analysis. Findings showed that there is a significant positive relationship between performance of SMES and entrepreneurship education as indicated by $r$ value of $=0.79$ at 0.05 level of significance. Also, acquired technical know-how has improved traders' business turnover showing a value of $r=0.75$ at 0.05 level of significance. The study concluded that entrepreneurship education is the major ingredient that traders in Anambra State need in order to improve their business, technical know-how, mindset, turnover and other aspects of their businesses to achieve maximum profit. The study recommended that government of Anambra State need to create a conducive entrepreneurship centers within the business eco-systems to enable SMEs operators attend workshops when slated. Government agencies in charge of Trade and Commerce in Anambra State need to guide and assist traders by offering them financial aid, infrastructure as required and less taxation.
\end{abstract}




\subsection{BACKGROUND OF THE STUDY}

Anambra State remains the only State with high population density of mainly businessmen and women (Onwuejeogwu 2008). Business activities in the State before the early 90 s made the State a popular one in West African Markets. Today's business activity among traders in Anambra State seems to be changing from what it was formerly known for (especially the Small Scale businesses). This is basically because of globalization, inadequate financial resources, poor business connections, lack of adequate experience, inability to cope with competition, poor sales and high stock of inventory, high operating costs as a result of poor infrastructure, inefficient management, poor business education (Afam 1999). Educational background and other demographic characteristics make some investors feel more competent than others in understanding the area of financial information and opportunities available to them. This of course makes the medium/large scale investors more opportune than Small Scale Business Investors due to their educational background. This according to Afam (1999) means that the level of education of traders are poor. In essence, these group of traders need to be enlightened in order to make them competent in contemporary business environment, equip them with necessary skills to cope with economic challenges in today's business world.

A trader has been described as a person whose job is to buy and sell things. Also, a trader is an individual who engages in the buying and selling of financial assets in any financial market, either for him or on behalf of another person/institution. Despite the issue of economic challenges facing today's business world of which Anambra State is not an exception, traders need managerial competence in business in order to progress. These businessmen are mostly those medium/large scale investors that have expanded their business knowledge or mindset. They have employees including apprentices and customers. They remain confident and can withstand any business challenges since they have the necessary skills, abilities, knowledge and other competencies which underlie effective performance. However, medium/large scale investors as mentioned above are much more equipped with managerial skills and technical know-how required in business environment for the actualization of their goal(s). Aderemi (2007) states that those owner-managers of small businesses who had undergone training in entrepreneurship programs have exhibited superior managerial practice and venture growth when compared to owner-managers who had not undergone such training programmes. These groups of traders/investors (those who had undergone entrepreneurship training) are more connected, have significantly large sales and value added than less connected traders.

The issue remains how these skills can be inculcated into traders - small scale business investors in Anambra State to improve their performances, and increase the revenue generation in the State. This calls for initiative to use the power of education to enhance the individual traders' mindset, and raise awareness of entrepreneurship as a viable alternative for traders. Upon this background it becomes crucial to research on 'entrepreneurship education and managerial competence among traders in Anambra State'.

\subsection{STATEMENT OF THE PROBLEM}

Nigeria's recent economic recession brought about deep challenges on many fronts, particularly in the already fragile entrepreneurial front and the much sought-after private sector. Anambra traders (entrepreneurs) seem to be generally products of homegrown apprenticeship schemes. They depend largely on traditional, in-house methods and practices. This accounts for the severe effects on their businesses when disaster calls or when business trend is disrupted. It also accounts for the difficulty they exhibit in charting new courses. This difficulty became glaringly evident with market fire disasters and occasional government crackdowns (for example, the Niger Bridge Head Drug Market crackdown during the fake drug syndrome), which drove many businesses to fold up and their proprietors into abject poverty. In a similar way, the negative effect of recession on small and medium scale businesses, the bastion of private sector entrepreneurship, and the bulwark of Anambra State's business activities, have persisted and have even increased, notwithstanding efforts by all and sundry to address the established determinants of entrepreneurial success. These determinants include funding, incentive schemes and private property rights.

One area yet to be explored by many researchers and which requires urgent investigative attention, with a view to policy action that may lead to the goal, is entrepreneurship education. Entrepreneurship Education is critical to successful enterprise setting due primarily to the fact that enterprise setting devoid of entrepreneurship education has greater chances of failure due to poor preparation for the challenges linked with business Start-ups, Ndubuisi-Okolo, Anigbogu and Onwuzuligbo (2014). It can be argued that with adequate entrepreneurship education, traders can respond to economic challenges and globalization trends in a manner that assures business survival, 
growth and competence. They can in fact change course when fortune crash or prospects dim, and as such can grow their businesses and prosper, irrespective of challenges emanating from within or without polity. How has it been with traders in Anambra State, a leading entrepreneurship State in Nigeria? This is what this study intends to establish.

\subsection{OBJECTIVES OF THE STUDY}

The general objective of the study is to ascertain the extent to which entrepreneurship education affects managerial competence among traders in Anambra State. Specifically, the study sets to achieve the following objectives:

1. To ascertain the effect of participating in business workshop on performance of small and medium scale enterprises in Anambra State.

2. To evaluate the effect of acquired technical know-how on turnover of Small Scale enterprises in Anambra State.

\subsection{RESEARCH QUESTIONS}

1. What is the relationship between performance of small and medium scale enterprises and entrepreneurship education?

2. To what extent has traders' business turnover improved through acquired technical knowhow?

\subsection{RESEARCH HYPOTHESES}

$\mathrm{H}_{01} \quad$ There is no significant relationship between performance of small and medium scale enterprises and entrepreneurship education.

$\mathrm{H}_{02}$ Acquired technical know-how has not improved traders' business turnover.

\subsection{SIGNIFICANCE OF THE STUDY}

This study will provide traders especially Small Scale Investors in Anambra State with knowledge on the effect of entrepreneurship education on their entrepreneurial and managerial competence. This will enable them to identify the challenges and prevailing factors militating against their success, and equip them with the necessary skills to proceed to take appropriate actions towards alleviating or solving them.

It will be of great benefit to unemployed graduates intending to engage in business ventures. It will unveil business secrets to them that will move them from job seekers to job providers.

This study will also be an eye-opener to the government of Anambra State to the areas in which they can assist the traders to improve their businesses thereby increasing their profit as well as the internal revenue generated in the State.

Finally, it will be significant to future researchers and academic institutions as it will serve as a reference material.

\subsection{SCOPE OF THE STUDY}

To achieve a useful and research-oriented study, the research was delimited to major business cities (Roads) in Anambra State: Awka and Onitsha.

\subsection{LIMITATIONS OF THE STUDY}

The researcher encountered setbacks due to fear and unfriendly attitude of the respondents. Some of the respondents refused to open-up and rejected the questionnaire due to ignorance. But the problem was mitigated by counseling and convincing them of the benefit they will derive from the study and assuring them that it is not meant for increment in their tax rate. This prompted their assistance in completing the questionnaire and opening up to the researcher.

\section{REVIEW OF RELATED LITERATURE 2.1 Conceptual Review 2.1.1 Concept of Entrepreneurship Education}

An Entrepreneur is a person who makes money by starting or running business especially when this involves making financial risks (Advanced Learners Dictionary $8^{\text {th }}$ Ed.). This word 'entrepreneur' comes from the Latin word "entreprendre" meaning to do something. It was originally used in the middle ages in the sense of a "person" who is active, who gets things done (Hoselitz 1951). Sehgal (2011) refers to an entrepreneur as one who creates his own business that is, a person who organizes, operates and assumes the risk of a business venture. $\mathrm{He}$ added that an entrepreneur is one who perceives a need and then brings together manpower, material and capital required to meet the need. He can be a trader, enterpriser, speculator or tycoon. An entrepreneur is also "one who can transform raw materials into goods and services, who can effectively utilize physical and financial resources for creating wealth, income and employment, who can innovate new products standard or upgrade existing product(s) for creating new markets and new customers. An entrepreneur can also be viewed as a change agent, an innovator who is also a risk taker, who exploits business opportunities in his environment and utilizes resources effectively to develop new technologies, produces new products and services to maximize his profits while contributing significantly to society's development. Ayatse (2013) added that the entrepreneur is one who is imbued with 
the ability, skill, competence and knowledge to organize a business venture with the desire to achieve valued goals or results".

Entrepreneurship is "the act of starting a company, arranging business deals and taking risks in order to make profit through the education skills acquired. It is a process of starting a business wiyhin or outside one's environment.

\section{Entrepreneurship Education}

Education is generally acknowledged as the panacea for socio-economic development in any country. Its importance in development activities of any nation cannot be over-emphasized. Adam (2017) stressed that "education is a sure pathway to liberation of the mind and the importance of socio-economic development in any nation. That is why many governments and international agencies are constantly making serious efforts both in developed and developing countries to develop the educational sector. Although a number of achievements have been made in this regard in Nigeria, a lot still need to be done to meet the ever increasing demands and challenges posed by rising business failure in today's business ecosystem. Thus, Obandan (2013) opined that under the present circumstances the need for education as a driver of development has become self -evident and inescapable. When people are poorly trained or are without skills, then education has failed to serve effectively as a growth driver. This means that major aim of education is to ensure that learning needs of both old and young people are met through equitable access to appropriate learning and life skills. In line with this Ayatse (2013) added that "education should be designed with a view to create and enhance the supply of entrepreneurial initiative and activities. That is to inculcate the spirit of entrepreneurship in the people via education". Indeed, to achieve it there must be serious adjustment of policies in line with demand of the present time.

Entrepreneurship Education is an educational programme that provides the students with knowledge, skills and motivation needed to start small and medium scale businesses. In other words, it promotes innovation, introduces new products or services and makes strategies which help the student to become outstanding entrepreneurs (Adam, 2013). Adam added that it is an educational discipline that prepares people especially youths to be responsible, enterprising, innovative and creative personalities who become entrepreneurs or entrepreneurial thinkers that contribute to economic development and sustainable communities. It is a programme designed to provide discipline to an individual to assume the responsibility and the risk for a business operation with the expectation of making a profit. If this succeeds the entrepreneur reaps profits and if it fails, he/she bears the loss. Thus,
Entrepreneurship education provides creative, innovative skills and knowledge needed to start and grow a business enterprise. It prepares individuals to create and successfully operate a business enterprise. Entrepreneurship education contributes in many ways towards creating new jobs, wealth, and income generation for both government and individuals.

\section{Managerial Competence}

Competency has a number of definitions which depend on the specific task to be performed by individuals under different conditions. It was popularized first by Boyatzis (1982) as a capacity that exists in a person that leads to behavior that meets the job demands within the parameters of organizational environment, and that, in turn brings about desired results". It is composed of knowledge, skills, abilities and other characteristics which underlie effective or successful job performance.Managerial Competencies are the skills, motives and attitudes necessary to a job, and include such characteristics as communication skills, problem solving, customer focus and the ability to work within a team (www.ehow.com) Konigova (2012) supports this by defining managerial competency as activities, knowledge, skills or attitudes and perhaps personal characteristics necessary to improve management performance.

\subsection{Theoretical Framework}

This research study is anchored on the following theories: McClland theory of Needs in which he stated that the n'ach people desire success and are afraid of failure. They desire challenging but achievable goals (Ezimma 2009). Kwabena (2014) added that achievement theory explained that human beings have a need to succeed, accomplish, excel or achieve; Alderfer's ERG theory which suggested that people can have the drive to fulfill three needs (need for Existence, Relatedness and growth) at a time and pursue them simultaneously; Personality traits theory which indicates stable qualities that a person shows in most situations. It gives a clue of the inborn or trait potentials - such as entrepreneurs tend to be more opportunity driven, hardworking, optimistic, they show intense commitment and perseverance, they rely on competitive desire to excel and win, they tend to be dissatisfied with the status quo and desire improvement, they are transformational in nature, they are lifelong learners and use failure as a tool and springboard, they believe that they can personally make a difference, they are individuals of integrity and above all visionary. Personality Traits theory looks at individual characteristics or behaviours and concludes that he/she has the inborn quality to become an entrepreneur (Kwabena 2014).

Furthermore, the study is anchored on Sociological entrepreneurship theory which focuses on 
the social context that is on building social relationships and bonds that promote trust and not opportunism. This theory states that entrepreneur should not take undue advantage of people to be successful rather success comes as a result of keeping faith with the people (Kwabena 2014).

The relevance of these theories to the study is that traders' attitude to business performance depends on the entrepreneurship training/education and skills they have acquired which positively change their mindset for maximum achievement/profitability.

McClelland theory suit this study in the sense that through the desire for success traders tends to seek for enlightenment on how to plan, execute their business, they try to dig out the secret of business success through education/training in order to maximize their profit level. With the knowledge they acquire, fear of failure disappears and the zeal for success increases in them. On the other hand, Alderfer's ERG theory assists traders (SMES) in socialization. Having good business relationship with others, that is, knowing the need for more business connections and not sticking to one business (which may not be booming), thereby achieving business growth through its positive business performance.

\subsection{Empirical Review/ studies}

Angga et at (2017) did a study on the effect of entrepreneurship education on entrepreneurial intention mediated by motivation and attitude among management students. The aim of the study was to investigate the effect of entrepreneurship education on entrepreneurial intention among students. The research employed descriptive correlation design and a population of 230 students were taken randomly as sample from 540 students enrolled in three study programs. Path analysis utilizing LISREL 8.50 for windows is used to examine relationship among variables. Research findings revealed that entrepreneurial intention is indirectly affected by entrepreneurship education, meaning that students' entrepreneurial motivation and attitude are two important mediating variables.
Ezeanokwasa (2014) conducted a study on Human resource development and organizational performance. The objective of the study was to evaluate the effect of human resource development on organization performance in Anambra State. A total of 100 participants responded to the questionnaire that measures human resource development and organizational performance. Chi-square statistical method was used to analyze the data collected which compares respondents, actual responses/observation with expected answers. Results indicated that there is a relationship between Human Development and Organizational performance. It provides an insight for the management to use this development as a tool for organizational effectiveness and profitability.

Gap in Knowledge

Researchers discovered paucity of empirical literature on entrepreneurship education and managerial competency among SMEs in Anambra State. This discovery precipitated the innate desire to delve into the topic in order to establish the relations between some decomposed variables of entrepreneurship education and managerial competency. This becomes the lacuna this study intends to fill.

\section{METHODOLOGY}

\subsection{Research Design}

The study employed descriptive survey research design which aimed at collecting detailed and factual information that described the phenomenon associated with the subject matter. This survey design became appropriate for this study because data is gathered directly from the respondents using structured questionnaire, interview and observation (Onyeizugbe, 2013).

\subsection{Population of the Study}

The total population of the study is 386 comprising traders (owners of the business), apprentices and managers of the two selected cities. 
ISSN (Online): 2455-3662

EPRA International Journal of Multidisciplinary Research (IJMR) - Peer Reviewed Journal Volume: 6 | Issue: 5 | May 2020 || Journal DOI: 10.36713/epra2013 || SJIF Impact Factor: 7.032 ||ISI Value: 1.188

Table 1:Population of traders in the selected Cities

\begin{tabular}{|c|c|c|c|c|}
\hline S/N & CATEGORY & ONITSHA & AWKA & TOTAL \\
\hline 1 & Owners & 161 & 153 & 314 \\
2 & Apprentice & 24 & 20 & 44 \\
3 & Managers & 16 & 12 & 28 \\
\hline & TOTAL & 201 & 185 & 386 \\
\hline
\end{tabular}

\subsection{Sample Size and Sample Technique}

In order to ensure fairness in the sampling of data required for investigation, the study randomized the entire population of 386. This is to enable sample score in the population of interest the chances of being included in the sample selection. To determine the sample size (n) from the population of the study, Taro Yamane's(1964) formula was utilized thus:

$$
\begin{aligned}
& \mathrm{n}=\underline{N} \\
& 1+N(\mathrm{e})^{2} \\
& \mathrm{n}=\quad \frac{386}{1=386(0.0025)} \\
& \mathrm{n}=\quad \underline{386} \\
& \mathrm{n}=\quad \underline{386} \\
& n=196.4^{1.965^{2}}=\quad 196 \text { respondents }
\end{aligned}
$$

Therefore, 196 were selected from the two selected cities as research respondents for the study. In order to determine the sample of each category of traders from each city Bowley's Proportionate Sample Allocation Techniques was employed. The formula is given below as:

$\mathrm{n}^{\mathrm{i}}=\underline{\mathrm{n}^{\mathrm{x}} \mathrm{xk}}$

$\mathrm{n}$

Where $\mathrm{n}^{1}=$ Proportionate sample size for the ith $(\mathrm{I}=1,2)$ cities

$\mathrm{n}^{\mathrm{x}}=$ Sample size derived using equation (1)

$\mathrm{k}=$ Proportion population for the ith of the cities $(1=1,2)$

$\mathrm{N}=$ Aggregate population of traders of selected cities

Onitsha managers

$$
\mathrm{no}_{1}=\frac{196 \times 16}{386}=\frac{3136}{386}=8.12 \approx 8 \text { respondents }
$$

Therefore, 8 managers were selected from Onitsha as research respondents.

Apprentices

$$
\mathrm{no}_{2}=\frac{196 \times 24}{386}=\frac{4704}{386}=12.1 \approx 12 \text { respondents }
$$

Therefore, 12 apprentices were selected from Onitsha as research respondents.

$$
\mathrm{no}_{3}=\frac{196 \times 161}{386}=\frac{31,556}{386}=81.75 \approx 82 \text { respondents }
$$

Therefore, 82 owners were selected from Onitsha as research respondents. 
Awka city Managers

no $_{1}=\frac{196 \times 12}{386}=\frac{2352}{386} \quad 6.0 \approx 6$ respondents

Therefore, 6 managers were selected from Awka city as research respondents.

Apprentices

$\mathrm{no}_{2}=\frac{196 \times 20}{386}=\frac{3920}{386}=10.1 \approx 10$ respondents

Therefore, 10 apprentices were selected from Awka city as research respondents.

Owners

$$
\mathrm{no}_{3}=\frac{196 \times 153}{386}=\frac{29988}{386}=77.6 \approx 78 \text { respondents }
$$

Therefore, 78 owners were selected from Awka as research respondents.

Table 2:Sample of Respondents from the selected Cities

\begin{tabular}{|c|c|c|c|}
\hline Traders category & Onitsha & Awka & Total Sample \\
\hline Owners & 82 & 78 & 160 \\
Apprentices & 12 & 10 & 22 \\
Managers & 8 & 6 & 14 \\
\hline TOTAL & $\mathbf{1 0 2}$ & $\mathbf{9 4}$ & $\mathbf{1 9 6}$ \\
\hline
\end{tabular}

\subsection{Sources of Data}

In carrying out this research study the data were collected from both Primary and Secondary sources. The primary data was generated through the use of structured questionnaire to elicit required information. Copies of which were administered and the participants were placed on objective response for each statement on a Five Point Likert Scale ranging from Strongly Agree $=5$, Agree $=4$, Disagree $=3$, Strongly Disagree $=2$ to Undecided $=1$.

\subsection{Validity of the Instrument}

To test the validity of the instrument (questionnaire), content validity test was done. Content validity was established by asking recognized experts in the field to review the survey instrument for clarity, comprehension, and consistency of question format. The research instrument was adjusted according to the suggestions and recommendations from the experts.

\subsection{Reliability of the Instrument}

The instrument was subjected to test-retest method and was also confirmed using Cronbach Coefficient Alpha to adjudge its good fit for the study. The result was 0.709 as shown below:

Reliability Analysis: The reliability of the research instrument was ascertained using Cronbach Alpha Coefficient and factor analysis. 


\section{Table 3 Reliability Statistics}

\begin{tabular}{|l|l|}
\hline Cronbach Alpha & No of items \\
\hline .709 & 16 \\
\hline
\end{tabular}

A cronbach \# alpha coefficient was obtained which showed that instrument is reliable.

Table 4 KMO and Bartlett's Test

\begin{tabular}{|l|l|}
\hline Kaiser-Meyer-Olkin Measure of Sampling Adequacy. & .720 \\
Bartlett's Test of Sphericity Approx. Chi-Square & $1.503 \mathrm{E} 3$ \\
Df & 150 \\
Sig. & .000 \\
\hline
\end{tabular}

The p-value of 0.000 from the KMO and Bartlett's Test also showed that the individual variables in the research instrument are sufficiently correlated.

\subsection{Method of Data Analysis}

The data gathered from the structured questionnaire were presented using descriptive statistics in graphs, charts and figures. A test of significance was conducted to determine the acceptance or rejection of the stated hypotheses first using the Pearson Product Moment Correlation Coefficient ${ }^{\circledR}$ to determine the strength of relationship between the dependent variable $\mathrm{X}$ (entrepreneurship education) and independent variable $\mathrm{Y}$ (managerial competence).

It value is between $-1\langle\mathrm{r}\rangle+1$.

$$
\mathrm{n} \sum x y-\left(\sum x\right)\left(\sum y\right)
$$

r $\quad=$

$$
\sqrt{n}\left(\sum \mathrm{x}^{2}\right)-\left(\sum \mathrm{x}\right)^{2} \sqrt{\mathrm{n}}\left(\overline{\left.\sum y\right)^{2}-\left(\sum y\right)^{2}}\right.
$$

Where,

$\mathrm{r}=$ Correlation Coefficient

$\mathrm{x}=$ Dependent Variables

$y=$ Independent variables

$\mathrm{n}=$ Number of Scores

To establish the significance of the result of the correlation analysis, the $t$ - statistics was used and is expressed thus:

$$
T=\frac{N / I}{\sqrt{1-r}}
$$

Decision Rule

Reject $\mathrm{H}_{0}$ if the computed value of $\mathrm{Z}$ is greater than the critical value of $\mathrm{Z}(\mathrm{Zc}>\mathrm{Zt})$. Do not reject $\mathrm{H}_{0}$ if otherwise.; 


\section{ANALYSIS}

The analyses of the data collected in the study are presented as follows:

Table 1 Questionnaire Response Rate

\begin{tabular}{|c|c|c|}
\hline Questionnaire & Number & Percentage \% \\
\hline Questionnaire Administered & 196 & 100 \\
\hline Questionnaire not returned & 16 & 8.16 \\
\hline Questionnaire returned & 180 & 91.84 \\
\hline
\end{tabular}

Source: field Survey, 2018

Table 1 above indicates that one hundred and ninety six (196) copies questionnaire was distributed to the respondents out of which one hundred and eighty (180) were completely filled and returned. This shows that the response rate for the survey is $91.84 \%$ hence 190 copies (91.84\%) of the questionnaire were used for the analysis.

\section{Hypothesis Testing}

Data gathered for the two hypotheses are as follows:

Generation of Data for the first hypothesis

$\mathrm{H}_{01}$ : There is no significant relationship between performance of Small/Medium Scale enterprises and entrepreneurship education.

$\mathrm{H}_{\mathrm{al}}$ : There is significant relationship between performance of Small/Medium Scale enterprises and entrepreneurship education.

Table 2

Summary of response to Questionnaire items relating to Hypothesis one:

\begin{tabular}{|c|c|c|c|}
\hline Questionnaire Items & No. of Respondents & $\begin{array}{c}\text { Sum of Response for } \\
\mathbf{( x )}\end{array}$ & $\begin{array}{c}\text { Number of Response } \\
\text { for (y) }\end{array}$ \\
\hline $1-4$ (PSMSE) & 180 & 1914 & \\
\hline $1-4$ (EEDU) & 180 & & 2603 \\
\hline
\end{tabular}

Table 2 shows that the summary of responses to questionnaire items to hypothesis one, which will be used to test hypothesis one. Details of the responses to these questionnaire items are presented in appendix 1 . Table 2 shows that the sum of the responses to PSMSE (X) is $£ x=1914$ while the sum of responses for EEDU (y) is $£ y=2603$ for the 180 respondents.

\section{Generation of Data for Test of Hypotheses 2}

$\mathrm{H}_{02}$ : Acquired technical know-how has not improved traders' business turnover.

$\mathrm{H}_{\mathrm{a} 2}$ : Acquired technical know-how has improved traders' business turnover.

Table 3:

Summary of Response to Questionnaire items relating to Hypothesis two

\begin{tabular}{|c|c|c|c|}
\hline Questionnaire items & No. of Respondents & $\begin{array}{c}\text { Sum of Response for } \\
\text { (x) }\end{array}$ & $\begin{array}{c}\text { No. of Response for } \\
\text { (y) }\end{array}$ \\
\hline $1-4$ (ATK) & 180 & 1945 & \\
\hline $1-4$ (TBS) & 180 & & 2509 \\
\hline
\end{tabular}

\section{Test for Hypothesis One}

Step 1 Research Question

To what extent has performance of Small/Medium Scale enterprises (PSMSE) relates to entrepreneurship education (EEDU)?

Step 2 Assumption.

The test of this hypothesis is based on the assumption that :

a. The sampling distribution of the scores of the respondents is normal.

Step 3

ii. Sampling distribution of the sum of the scores are independent. 
$\mathrm{H}_{01} \quad$ There is no significant relationship between performance of Small/Medium Scale enterprises and entrepreneurship education.

$\mathrm{H}_{\mathrm{a} 1} \quad$ There is significant relationship between performance of Small/Medium Scale enterprises and entrepreneurship education.

Computation of $r, r^{2}$ and tc

Table 4

Test of hypothesis 1: summary of data derived from Appendix 1

\begin{tabular}{|c|c|c|c|c|c|}
\hline Sample size & $\mathbf{\Sigma} \mathbf{x}$ & $\boldsymbol{\Sigma} \mathbf{y}$ & $\boldsymbol{\Sigma} \mathbf{x y}$ & $\boldsymbol{\Sigma} \mathbf{x}^{\mathbf{2}}$ & $\boldsymbol{\Sigma} \mathbf{y}^{\mathbf{2}}$ \\
\hline 180 & 1914 & 2603 & 28144 & 20820 & 38389 \\
\hline
\end{tabular}

Table 3 shows the summary of independent variable (x) and the dependent variable (y). Computations needed to test hypothesis 1 . Details of the data used in this computation are shown in appendix 4 . Number of respondents $=$ $180, \quad \sum \mathrm{x}=1914, \quad \sum \mathrm{y}=2603, \quad \sum \mathrm{x}^{2}=20820, \quad \sum \mathrm{xy}=28144$ and $\sum \mathrm{y}^{2}=38389$

$r=\quad \frac{n \sum x y-\sum x \sum y}{\sqrt{\left(n\left(\sum x^{2}\right)-\left(\sum x\right)^{2}\right)\left(n \sum y^{2}-\left(\sum y\right)^{2}\right)}}$
$r=\quad \frac{196(28144)-(1914)(2603)}{\left.\sqrt{\left[180(20820)-(1914)^{2}\right]\left[180(38389)-(2603)^{2}\right.}\right]}$
$r=0.7874=0.79$

Coefficient of Determination

$r^{2}=0.6241=0.62$

$\mathrm{t}_{\mathrm{c}}=\mathrm{r} \sqrt{\frac{\mathrm{n}-2}{1-\mathrm{r}^{2}}}$

$=\quad 0.79 \quad \sqrt{\frac{180-2}{1-0.62}}$

$=10.88$

For hypothesis $1: \mathrm{r}=0.79, \mathrm{r} 2=0.62$ and $\mathrm{tc}=10.88$

Step 5: Decision Rule

At 0.05 level of significance reject Ho if the computed $t$-value exceeds the critical $t$-value or is less than the negative critical t-value. 
Figure 1

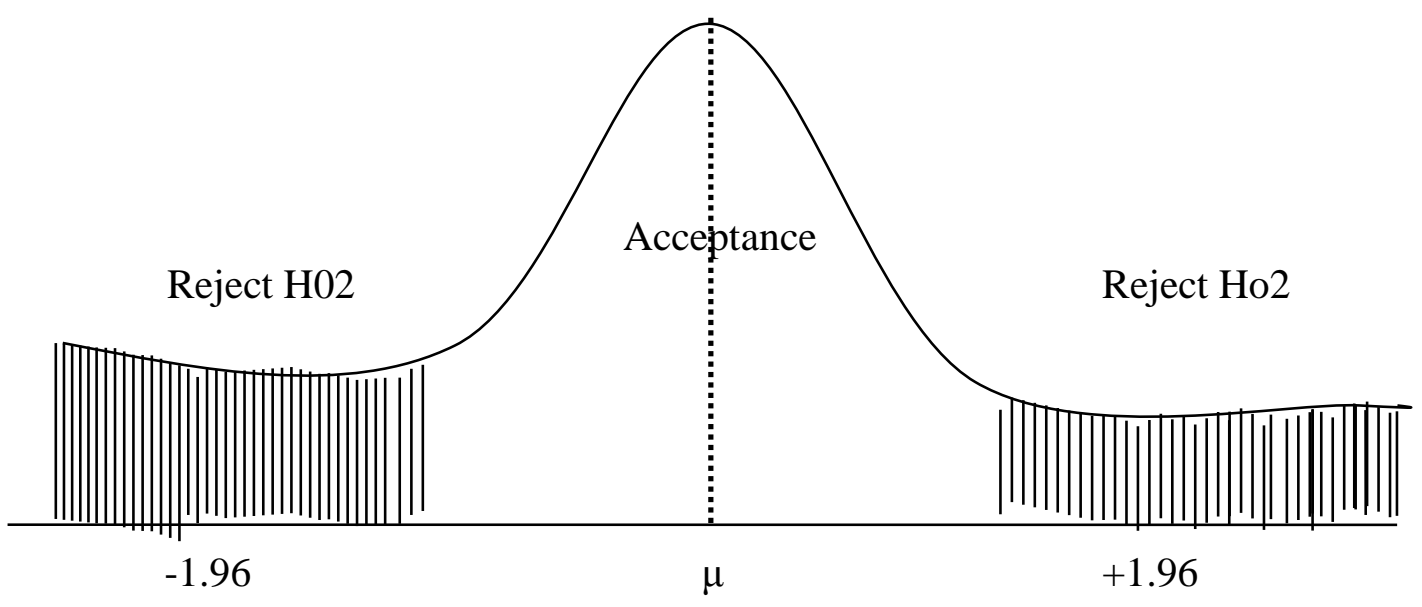

Figure 1:Student Distribution Curve showing Rejection and Acceptance Decision Regions for Hypothesis 1.

Step 6: Decision:

At 0.05 level of significance, the calculated $t$-value of 10.88 is greater than the critical t-value of 1.96 , so the study rejects the null hypothesis (there is no significant relationship between performance of small and medium scale enterprises and entrepreneurship education) and accept the alternate hypothesis (there is significant relationship between performance of small and medium scale enterprises and entrepreneurship education).

Step 7: Interpretation:

There is significant relationship between performance of small and medium scale enterprises and entrepreneurship education.

\section{Test of Hypothesis Two}

Step 1

Research question

To what extent has traders' business turnover improved through acquired technical know-how?

Step 2

Assumption

The test of this hypothesis is based on the assumption that

a. The sampling distribution of the scores of the respondents is normal

b. Sampling distribution of the sum of the scores and independent

Step 3: Statement of the Hypothesis

$\mathrm{H}_{02} \quad$ Acquired technical know-how has not improved traders' business turnover

$\mathrm{Ha}_{2} \quad$ Acquired technical know-how has improved traders' business turnover.

Step 4

Test of Hypothesis 2: Summary of data derived from Appendix 2.

Table 5

\begin{tabular}{|l|l|l|l|l|l|}
\hline Sample size $(\mathrm{x})$ & $\sum \mathrm{x}$ & $\sum \mathrm{y}$ & $\sum \mathrm{xy}$ & $\sum \mathrm{x}^{2}$ & $\sum \mathrm{y}^{2}$ \\
\hline 180 & 1945 & 2599 & 28305 & 21365 & 37867 \\
\hline
\end{tabular}

Source: Field survey 2018 
Table 5 shows that summary of independent variable $(\mathrm{x})$ and dependent variable $(\mathrm{y})$ computation needed to test hypothesis two. Details of the data used in this computation are presented in appendix 2.

$\mathrm{r}=$

$$
\frac{\mathrm{n} \sum \mathrm{xy}-\left(\sum \mathrm{x}\right)\left(\sum \mathrm{y}\right)}{\sqrt{\left(\mathrm{n} \sum \mathrm{x}^{2}-\left(\sum \mathrm{x}\right)^{2}\left(\mathrm{n} \sum \mathrm{y}^{2}-\left(\sum \mathrm{y}\right)^{2}\right)\right.}}
$$

$$
180(28305)-(1945)(2597)
$$

$\mathrm{r}=$

$$
\sqrt{\left.\overline{\left(180(21365)-(1945)^{2}\right)\left(\left[180(37867)-(2597)^{2}\right.\right.}\right)}
$$

r 0.75091

Coefficient of Determination

$r=0.75, r^{2}=0.58$

$$
\begin{aligned}
& t_{c}=\sqrt[r]{\frac{\mathrm{n}-2}{1-\mathrm{r}^{2}}} \\
& =\quad 0.75 \quad \sqrt{\frac{180-2}{1-0.56}}
\end{aligned}
$$

$=15.08$

For hypothesis two we have $\mathrm{r}=0.75, \mathrm{r}^{2}=0.56, \mathrm{t}_{\mathrm{c}}=15.06$

\section{Step 5 Decision rule:}

At 0.05 level of significance, reject Ho if the computed t-value exceeds the critical t-value or is less than the negative critical t-value.

Figure 2
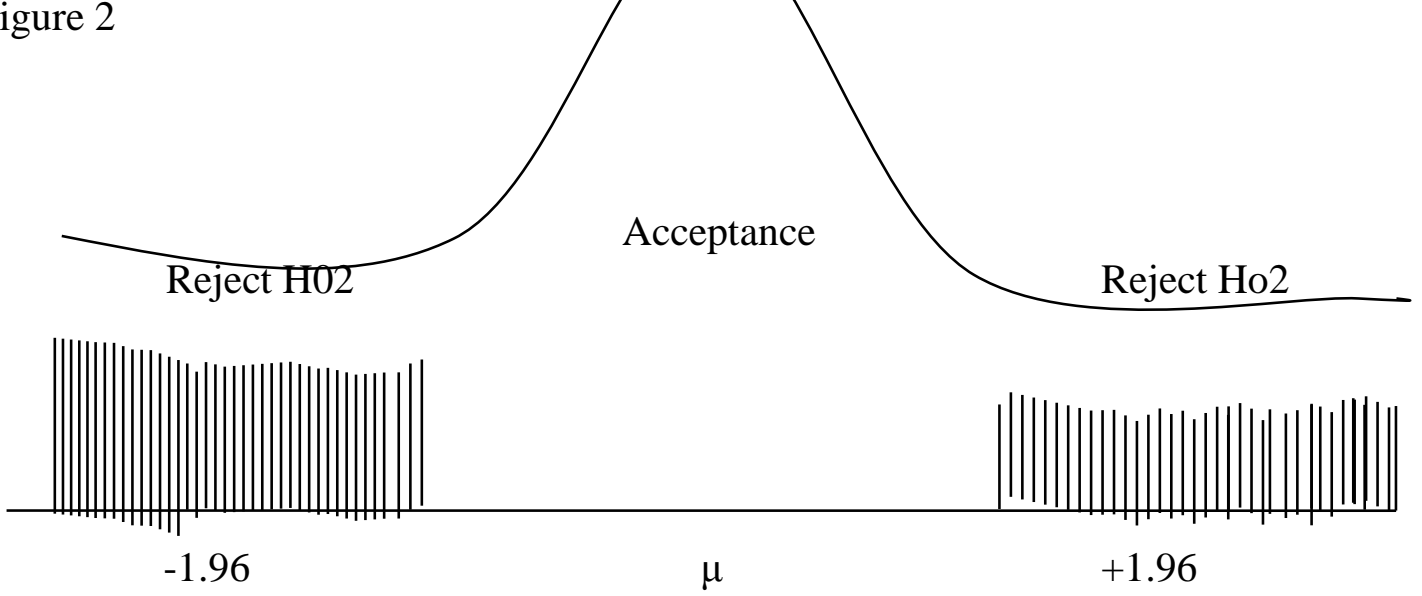

Figure 2:Student Distribution Curve showing Rejection and Acceptance Decision Regions for Hypothesis 2. 


\section{Step 6: Decision}

At 0.05 level of significance, the calculated t-value of 15.05 is greater than the critical t-value of 1.96 , so the study rejects the null hypothesis (Acquired technical know-how has not improved traders' business turnover) and accepted the alternate hypothesis (Acquired technical know-how has improved traders' turnover).

Step 7: Interpretation: Acquired technical know-how has improved traders' business turnover.

\section{SUMMARY OF FINDINGS, CONCLUSION AND RECOMMENDATIONS \\ 5.1 Summary of Findings}

The results showed that there is a significant relationship between

1. Performance of small and medium scale enterprises and entrepreneurship education $\mathrm{r}=$ 0.79 at 0.05 level of significance.

2. Also, acquired technical know-how has improved traders' business turnover indicating $\mathrm{r}=0.75$ at 0.05 level of significance.

\subsection{Conclusion}

The study confirms that entrepreneurship education is a very great tool in every business firm (SMES) that wants to survive in Anambra State. Findings showed that entrepreneurship education is the major ingredient that traders in Anambra State need in order to improve their business, technical know-how, mindset, turnover and other aspects of business in general in order to achieve maximum profit.

\subsection{Recommendations}

Based on the findings of the study, the following recommendations are considered suitable:

1. To actualize the major aim of this work, the small scale investors (traders) need to be enlightened more on both entrepreneurship making them to be more versatile in business in order to be able to effect changes when need be; and equip them with the necessary managerial competence/skills for managing the day-to-day affairs of their businesses in the face of incessant economic challenges in today's businesses.

2. Government of Anambra State need to create a conducive entrepreneurship centre within the business ecosystem to enable traders attend free workshops when scheduled. Traders can be informed about benefits of participating/attending business workshops through social media before slating any.

3. The workshops should be very close to the targeted markets. Government agencies in charge of trade and commerce in Anambra State should guide and assist traders by offering them financial aid, infrastructure as required and less taxation.

\section{REFERENCES}

1. Adam, A. A. (2017). Entrepreneurship Education and Employment in Nigeria. Retrieved from: www.hrmars.com on 6 December, 2017

2. Aham A. (1999). New Perspective of Entrepreneurial Development. Published by Kletken Publishers, Owerri.

3. Angga M. M. et al (2017). The effect of Entrepreneur Education on Entrepreneurial Intention Mediated by Motivation and Attitude among Management Students. Retrieved on $5^{\text {th }}$ February, 2019 from www.google,com .

4. Ayatse F.A. (2013). Driving Entrepreneurship Education in Nigeria: Issues and Challenges. International Journal of Business and Management Review. 1(4),European Centre for Research Training \& Development U. K. Retrieved on Jan. 2018 accessed from www.ea-journals.org.com

5. Baba G. K. (2013). The Challenges of Entrepreneurship Development in Nigeria and way forward.Journal of Business and organizational Development. 5 (1), $54-64$.

6. Education.From http://www.weforum.org/issues/education/ Retrieved on 6 Dec., 2017

7. Egbe, J. E. (2014). Business Studies. West African Book Publishers.

8. Entrepreneurship https:en.wikipeadia.org/wiki/entrepreneurship. Retrieved on 28 November, 2017

9. Ezeanokwasa (2014). Human Resource Development and Organizational Performance. A Journal of Information and Knowledge Management. 4(2).

10. Henry, Thomas (2012). Entrepreneurship skills for Growth-Oriented Businesses. Dublin Institute of Technology. Retrieved on 6 December, 2017

11. Konigova, M. (2012). Identification of Managerial Competencies in Knowledge base Organization. Retrieved from: Driving-EntrepreneurshipEducatuion-in-Nigeria-Issues-andchallenges[1].pdf on 04 December 2017

12. Kwabena (2014) Entrepreneurship theories and Empirical Research. European Journal of Business and Management ISSN 222-1905 Vol 3, No. 6; 2011. A Journal of Competitiveness Vol. 4, Issue 1 Retrieved from www.google.com . Accessed on $3^{\text {rd }}$ June, 2018.

13. Laura R. H. et al (2012). The Effect of Early Entrepreneurship Education. Retrieved from www.google.com accessed in June 2018.

14. Managerial Competence. Retrieved from www.ehow.com/info_8216837_managerial- 
ISSN (Online): 2455-3662

EPRA International Journal of Multidisciplinary Research (IJMR) - Peer Reviewed Journal Volume: 6 | Issue: 5 | May 2020 || Journal DOI: 10.36713/epra2013 || SJIF Impact Factor: 7.032 ||ISI Value: 1.188

competencies-mean.html . Accessed on 5

December, 2017

15. Ndubuisi-Okolo Purity Uzoamaka, Theresa Anigbuogu and (Rev.) Leonard Onwuzuligbo(2014). Entrepreneurship Education and Youth Development in Nigeria:The Nexus. International Journal of Advanced Multidisciplinary Research 1(3): (2014): 24-31

16. Nnabuife, E. (2009) Organizational Behaviour and Management Theory. Pg 90 Rex Charles \& Patrick Lts, Booksmith House, Nimo

17. Obadan, S. E. (2013) The Role of Secretarial Education in Nigeria Economic Development". Journal of Educational Research and Development 3:294-298. Retrieved from www.google.com on 6 December, 2017

18. Ojeifo (2013). Entrepreneurship Education. Journal of Business and Organizational Development Vol. 5, No. 1.

19. Onyeizugbe, C. U. (2013). Practical Guide to Research Methodology in Management p. 115 Good success Press, Onitsha

20. Retrieval from: https://www.merriam-webster.com on 5 December, 2017

21. Retrieval from: www.econlib.org $>C E E>2$ nd edition. Retrieved on 25 November, 2017.

22. Sehgal, M. K. (2011). Entrepreneurship Development: a Systematic Approach. UDH Publishers

23. Technical and Vocational Education and Training [TVET] and Entrepreneurship Skills 2012 retrieved from www.enevoc.unesco.org accessed on Dec., 2017.

\section{WEBSITES}

24. International Journal of Academic Research in Business and Social Sciences 2017 7( 3) ISSN 2222-6990. retrieved from www.google.com on 28 Nov. 2017

25. International Journal of Business and Management Review. 1(4), 83-88. Retrieved from: www.eajournals.org on December 4, 2017 